\title{
DIFFICULTIES IN DIAGNOSING INFANTILE SCURVY BEFORE 1878
}

\author{
by
}

\section{ELIZABETH LOMAX*}

Early nineteenth-century British paediatric authors usually wrote extensively about rickets while making no mention of infantile scurvy. The latter may indeed have been a rare disease among weanlings or, alternatively, one that escaped diagnosis. In the opinion of the paediatrician and historian, George Frederick Still, and of Morwenna and John Rendle-Short, some of the hazards formerly associated with teething were due to unrecognized scurvy. In an analysis of Joseph Hurlock's Practical treatise upon dentition or the breeding of teeth in children, published in 1742, Still commented as follows: "No doubt, in Hurlock's day, as in our own, unfortunate infants have had their swollen gums lanced to relieve what was supposed to be swelling due to mere dentition, when the purple swelling over a tooth just coming was really due to the haemorrhage of infantile scurvy." In their Life of William Cadogan, the Rendle-Shorts also intimated that scurvy was a contributory cause to teething problems in the eighteenth century. ${ }^{2}$ Nevertheless, the fact that late eighteenth- and early nineteenth-century physicians did not include scurvy in their assessments of weanling disorders tends to negate the view that the malady could have been commonplace. Thomas Barlow, who in 1883 gave a persuasive account of infantile scurvy, thought it probable that the illness had recently increased in incidence, since it was "inconceivable that men of the authority of Jenner and West and Hillier should not have insisted upon it if this group of symptoms had often occurred within the common range of their experience." 3

Five years earlier, in 1878, Walter B. Cheadle had described three instances of scurvy supervening on rickets in young children aged from sixteen months to three years. ${ }^{4}$ The conjunction of the two diseases intrigued him, for rickets was the commonest morbid condition found in patients admitted to the Hospital for Sick Children, Great Ormond Street, whereas cases of scurvy were extremely rare. Cheadle concluded that an almost entirely farinaceous diet known to be conducive to rickets would not produce scurvy unless potatoes were excluded, an unlikely event in

\footnotetext{
*Elizabeth Lomax, Medical History Division, Department of Anatomy, University of California, Los Angeles, California 90024, USA.

${ }^{1}$ George Frederick Still, History of paediatrics, London, Dawsons, 1965 (first ed. 1931), p.362.

'Morwenna and John Rendle-Short, The father of child care: life of William Cadogan (1711-1797), Bristol, John Wright, 1966, p.34.

'Thomas Barlow, 'The Bradshaw lecture on infantile scurvy and its relations to rickets', Br. med. J., 1894 , ii: $1029-1034$.

'Walter B. Cheadle, 'Three cases of scurvy supervening on rickets in young children', Lancet, 1878, ii: 685-687.
} 


\section{Difficulties in diagnosing infantile scurvy}

most households since potato mashed with gravy was a cheap and easily prepared food usually eagerly eaten by small children. Barlow also assumed that scurvy was rare among poor children because they were usually liberally fed with potatoes early in life. By 1894, he had seen thirty-three typical cases, of which twenty-seven were children from prosperous homes. ${ }^{5}$ The affluent were more likely to feed their children on the novel and relatively expensive proprietary infant foods, which Barlow believed to be deficient in some vital antiscorbutic quality, especially when prepared with water, or with condensed rather than natural milk.

For references to early childhood scurvy prior to Cheadle's 1878 paper one must return to the sixteenth- and seventeenth-century British medical literature. William Clowes, surgeon to Queen Elizabeth I, reported that he sometimes saw as many as twenty or thirty children at a time in Christ's Hospital afflicted with the "scorby". ${ }^{6}$ In his 1650 monograph, De rachitide, Francis Glisson had included a description of infantile scurvy as distinct from, but often superimposed upon, the rickets. ${ }^{7}$ Childhood scurvy was also recognized in seventeenth-century France. Marcel Colly has related how scurvy was diagnosed in 1640 among children reared at the Charité hospital in Lyons and ultimately cured through the use of a variety of remedies including a "scorbutic syrup" and oranges. ${ }^{8}$

Whereas French physicians continued occasionally to diagnose, or speculate as to the likelihood of, early childhood scurvy during the next two centuries, similar references are not to be found in British medical texts until 1878, apart from T.H. Tanner's conventional description of scurvy in his 1858 paediatric textbook. ${ }^{9}$ It should be emphasized here that the concern of the present paper is with "infantile scurvy", occurring in children from a few weeks to three years of age, and not with the malady in older children and adolescents which more closely resembles the adult form and was at times diagnosed in early nineteenth-century Britain. ${ }^{10}$ One such occasion followed the 1846 potato famine. In a paper published in 1847 , Charles Ritchie, a physician at the Glasgow Royal Infirmary, stated that of 122 cases of scurvy treated at the hospital, nine had been less than twenty years of age. ${ }^{11}$ Two had died, one a boy of sixteen and another aged eleven years, the former a miner and the latter a tobacco worker. Similarly, during the "cotton famine" of 1862 , instances of scurvy appeared among Lancashire and Cheshire workers trying to exist on a diet mainly composed of bread and tea, according to the Medical Officer's report to the

\footnotetext{
${ }^{5}$ Barlow, op. cit., note 3 above.

${ }^{6}$ F.N.L. Poynter (editor), Selected writings of William Clowes, 1544-1604, London, Harvey \& Blythe, 1948, p.121.

${ }^{7}$ Francis Glisson, De rachitide, 2nd ed., London, Th. Roycroft, 1660, pp.261-262.

${ }^{8}$ Marcel Colly, 'Le scorbut chez les enfants de l'Aumône Générale et de la Charité de Lyon aux XVIe et XVII' siècles', Cahiers Lyonnais Hist. Med., 1956, 1 (2): 33-40.

${ }^{9}$ I am grateful to Dr Thomas E. Cone, Jr, for drawing my attention to the following exception to the above generalization. In his Practical treatise on the diseases of infancy and childhood, London, Henry Renshaw, 1858, pp.194-195, T.H. Tanner discussed the symptoms and treatment of scurvy, prefacing his article with the statement that this malady did not often occur during childhood.

${ }^{10}$ Tanner, ibid., made no special reference to weanlings, and described the symptoms of scurvy as they would occur in older children and adults.

${ }^{11}$ Charles Ritchie, 'Contributions to the pathology and treatment of the scorbutus', Edinb. mthly J. med. Sci., 1847, 8: 38-49, 76-86.
} 


\section{Elizabeth Lomax}

Privy Council. ${ }^{12}$ Ages were not given, but one "poor girl", an operative who died of scurvy, may well have been a child by modern standards.

A decrease in the incidence of infantile scurvy would be the simplest explanation for its disappearance from the literature after Glisson's era. The eighteenth century witnessed not only improvements in farming and stock-raising but also in market gardening. Fields close to towns began to be used for growing fruit and vegetables for sale in the urban areas, leading to the availability of cheaper, fresher, and more varied produce. ${ }^{13}$ Among the vegetables being cultivated as cash crops were potatoes, cabbages, cauliflowers, and lettuce, all of which could contribute ascorbic acid to the diet. Most importantly perhaps for weanlings, potato consumption became more widespread, especially in northern England probably because of the Irish influence there. "Elsewhere", according to Drummond and Wilbraham, "the potato was regarded with much prejudice, white bread being commonly considered a greatly superior food."14 Nevertheless, even if young children were not given potatoes and green vegetables, they could benefit from an increased consumption by their mothers, since breast-feeding was usually continued for several months after the introduction of solid food. In 1869, fellows of the London Obstetrical Society were asked to reply to a questionnaire which included a section on lactation and feeding. On this topic the ensuing report went as follows:

Among the married poor suckling is evidently the rule, and a large amount of testimony is borne to the fact that it is often unduly protracted, even to eighteen months and two years, for the most part with the hope that it may prevent a rapid recurrence of pregnancy....Among the married poor also it appears nearly universal to give the child artificial food as well as the breast, and that from a very early date. ${ }^{15}$

Infants so reared would not have been candidates for scurvy. But what of children who were not suckled, or who were abruptly weaned at six or eight months? Furthermore, it is surprising that there were no reported instances of infantile scurvy during the potato and cotton famines when older children and young adults were succumbing to the disease. A partial explanation may have been the increase in breast-feeding that occurred during the latter famine due to the unemployment of married women operatives. "Lactation", according to Dr Buchanan, "has been noticed to be unwisely prolonged, the mothers pleading inability to purchase the food appropriate for a weaned child."16 Yet there remains the possibility that infantile scurvy was not being diagnosed because it was not being recognized.

Afflicted children would not have displayed clinical features identical to those found in adults. As Barlow was to stress, the most striking disturbance in small children was usually pain and irritability on any attempt to touch or move the lower

\footnotetext{
12،Dr. Buchanan's report on the health of operatives', Fifth annual report of the Medical Officer to the Privy Council, PP, 1863, XXV, pp.302 and 309.

${ }^{13}$ Jack C. Drummond and Anne Wilbraham, The Englishman's food: five centuries of English diet, London, Jonathan Cape, 1957, pp.182-183.

${ }^{14}$ Ibid., p.181. See also, Redcliffe N. Salaman, The history and social influence of the potato, Cambridge

University Press, 1949.

${ }^{15}$ 'Report of the infant mortality committee', Trans. obstet. Soc. Lond., 1869, 11: 132-149.

${ }^{16} \mathrm{PP}, 1863, \mathrm{XXV}, \mathrm{p} .301$.
} 


\section{Difficulties in diagnosing infantile scurvy}

limbs. ${ }^{17}$ Later, the legs would swell and be held perfectly still as if paralysed. At autopsy, he found the cause to be effusion of blood under the periosteum, a lesion that was associated with adult scurvy but not usually as a presenting feature. The classical sign of scurvy, spongy, sore and bleeding gums, would be absent in infants who had not yet begun teething, and would not be very obvious until several teeth had appeared. Nor would small children usually display the skin ulcers and rashes so frequently found in adults. Most misleading, however, would have been the probable coexistence of rickets, an assumption which can be made because the three cases first described by Cheadle, and the majority of Barlow's, were all of scurvy grafted on rickets.

Barlow pointed out that the combined disorder had been described in the German medical literature as "acute rickets". Julius Moeller is usually credited with the first description, in 1859 , and in his honour, infantile scurvy was often termed "die Moeller-Barlowsche Krankheit" in late nineteenth-century German paediatric texts. ${ }^{18}$ But other accounts of "acute rickets" had been published before 1859 . Johann Peter Frank appears to have coined the term, in 1788, to describe the case of a fourteen-year-old girl rather suddenly afflicted with a wry-neck. Soon, the girl was unable to walk and her life seemed threatened, but she was restored to perfect health with antirachitic remedies, Frank having decided that her malady was due to underlying rickets inherited from the mother. ${ }^{19}$ In 1839 , a French physician, Jules Guérin, described the early or acute stage of rickets as being characterized by pathological bony changes which, in retrospect, seem more suggestive of scurvy. ${ }^{20}$ His observations are worth closer examination since they served as the basis of later accounts of the pathology of "acute rickets".

Guérin envisioned three stages in the development of rickets. He indicated that the bones of children dying during the first period were hard to come by because fatalities rarely occurred at this point except from intercurrent illness, such as pneumonia. It was also difficult to sort out which symptoms during life were peculiar to rickets as opposed to the secondary infection. Early rickets, in his opinion, was characterized by diarrhoea, abundant night sweats, excessive tenderness of the limbs, disinclination and difficulty in standing, and slight swelling of the articulations. At autopsy, on cutting long bones longitudinally, he found remarkable quantities of sanguineous material in the medulla and in the spongy tissue at the level of the epiphyses. Reddish fluid was also to be found between the compact tissue lamellae and under the periosteum, which was slightly thickened and obviously infected. In short, according to Guérin, the first stage of rickets entailed a general extravasation of blood, less viscous and more fluid than normal, into all the bony interstices, but most obvious in the long bones. In the second stage, autopsy demonstrated the development of a new fine spongy tissue, which Guérin believed to be the product of

\footnotetext{
${ }^{17}$ Barlow, op. cit., note 3 above.

${ }^{18}$ Julius Moeller, 'Ueber akute Rachitis', Konigsb. med. Jb., 1859, 1: 377-379.

${ }^{19} \mathrm{~J} . P$. Frank, 'Discursus academicus de rachitide acuta, et adultorum', Delectus opusculorum medicorum, vol. 5, Pavia, 1788, pp.304-318.

${ }^{20} \mathrm{~J}$. Guérin, 'Mémoire sur les charactères généraux du rachitisme', Gaz. méd. (Paris), 1839, 7: 433-440, 449-455, 481-483.
} 


\section{Elizabeth Lomax}

organization of the earlier sanguineous fluid, but it is more likely that he was now seeing cases of simple rickets, whereas the previous ones had been scorbutic.

In 1854, Salomon Stiebel, a physician practising in Frankfurt, used Guérin's description of the pathological bony changes in early rickets to flesh out his own clinical account of "acute rickets". ${ }^{21}$ Chronic rickets, according to Stiebel, usually developed in later infancy, whereas the acute form occurred during the first six months of life, usually in babies fed artificially. The illness was ushered in by profuse perspiration of the head and neck, a rapid pulse, diarrhoea alternating with constipation, an enlarged abdomen associated with rapid emaciation of the rest of the body, and the infant was restless and appeared miserable. Soon, however, in marked contrast to a normal infant, who would delight in moving its limbs and trying to suck its toes, the little patient would lie with its legs perfectly still and extended. If they were touched, an expression of pain would cross the child's face, and shrieks would accompany attempts to lift or turn him. Evidence of so much pain would have been more applicable to scurvy than to rickets, as Barlow was later to indicate.

In preparing the article on rickets for his Dictionary of practical medicine (1858), James Copland used the three stages defined by Guérin, because "from considerable experience of the complaint, I believe the division to be useful, and to be based on sound observation." 22 His clinical account of the first stage mentioned pains in the joints and along the bones, but without the special emphasis on severe pain given by Stiebel, so it was far less suggestive of scurvy. The pathological section was an admitted summary of Guérin's findings, so although Copland had much to say about effusions of blood in the long bones during the first stage, there is no firm evidence that he himself had ever observed such changes. More specifically, A. Schoepf Merei, a Hungarian physician practising in Manchester, described the symptoms of "acute rickets" as given by German authors, with the disclaimer that he had not been struck by the existence of this form nor heard it mentioned in Manchester. ${ }^{23}$ His judgement was based on clinical features only, yet it carries some weight since rickets was a common illness in the Manchester area. Merei estimated that one-fifth of the children in his private practice were rickety. Later, in 1870, C. Currie Ritchie found that of 728 children under five years of age brought to the Hulme Dispensary, Manchester, 219 were rickety, i.e., about thirty per cent. ${ }^{24}$ In spite of this high incidence among children of all classes, rich and poor, physicians were apparently not seeing cases suggestive of "acute rickets", or else did not believe that this condition should be differentiated from classical rickets.

This second possibility was exemplified in William Jenner's lectures on rickets, delivered in 1859 and 1860 at Great Ormond Street Hospital for Sick Children. Incipient rickets, according to Jenner, was heralded by three symptoms: first, profuse sweating of the head and neck; second, kicking off the bedclothes by the child to keep

\footnotetext{
${ }^{21}$ Salomon Stiebel, 'Rachitis und Osteomalacie', in R.L.K. Virchow's Handbuch der spec. Path. u. Therap., 1854, 1: 527-551.

22James Copland, Dictionary of practical medicine, vol. 3, London, Longman, Brown, Green, Longmans, \& Roberts, 1858, pp.643-652.

${ }^{23}$ A. Schoepf Merei, On the disorders of infantile development and rickets, London, John Churchill, 1855, pp.154-155.

${ }^{24} \mathrm{C}$. Currie Ritchie, 'Clinical observations on rickets', Med. Times Gaz., 1871, 1: 9-11.
} 


\section{Difficulties in diagnosing infantile scurvy}

cool; and third, tenderness of the limbs. At this point, Jenner referred to Stiebel's 1854 paper and paraphrased the latter's description of an infant lying with extended legs as quietly as possible and crying at the least movement. But Jenner made no mention of "acute rickets", instead considering all the above symptoms as precursors of the classical disease. ${ }^{25}$ Degree of pain was indeed a most uncertain measure on which to balance disease differentiation, so it is easy to understand why many physicians, including German ones, were unimpressed by the claims for an acute form of rickets. Edward Henoch, professor at the University of Berlin and director of the paediatric department at the Charité, was quite scathing on the subject. "I have never seen any cases of rickets with an acute feverish course", he wrote in the 1889 edition of his textbook, "and as my cases have numbered many thousands, I therefore infer that this form of the disease must be very rare, if indeed it ever occurs at all." ${ }^{26} \mathrm{He}$ believed that rickets always ran a chronic course, that any rise in temperature observed was due to complications, such as bronchial catarrh, and he did not discuss the recent British findings on infantile scurvy here or elsewhere in his book.

As mentioned earlier in this paper, scurvy is sometimes also associated with spongy, swollen, bleeding gums in small children whose milk teeth have begun to erupt. Early nineteenth-century British paediatricians and dentists described severe inflammation of the gums as one of the complications of teething, but without bringing scurvy into the picture. An exception to this rule was Charles West, the founder of Great Ormond Street Hospital. After the usual description of normal primary dentition, he discussed complications including instances when the baby's gums became swollen, tense, red and injected, in his opinion requiring scarification to promote bleeding. However, he opposed lancing of the gums in the rare instances of even more intense inflammation accompanied by ulceration, a condition he termed "odontitis". Although he had never seen a fatal case, in three babies under his care the condition became chronic, continuing during the entire teething period. "The gum...was spongy and livid, like that of a person suffering from scurvy, and so swollen that the teeth were almost hidden by it, while an unhealthy ulceration of its edges surrounded each tooth." 27 Later West repeated the analogy: "The children...were weakly, and in one of them an eruption of the purpura, which appeared at the age of fifteen months, served to assimilate the character of the ailment even more closely to scurvy." ${ }^{28}$ The only treatment he found beneficial was "the employment of acids, quinine, and wine in small quantities", which leaves open the question of how profoundly he held scurvy under consideration. For, by the mid-nineteenth century, the antiscorbutic properties of citrus fruit were well established, as demonstrated in the account given by T.H. Tanner, the one physician who did describe scurvy as a disease occasionally occurring during childhood. ${ }^{29}$ The

${ }^{25}$ William Jenner, 'A series of three lectures on rickets; Lecture III', ibid., 1860, 1: 415-417.

${ }^{26} \mathrm{E}$. Henoch, Lectures on children's diseases, vol. 2, (trans. from the 1889 German ed.), London, New Sydenham Society, 1889, p.399.

${ }^{27}$ Charles West, Lectures on the diseases of infancy and childhood, (from the 1865 English ed.), Philadelphia, Henry C. Lea, 1866, p.457.

${ }^{28}$ Ibid.

${ }^{29}$ See note 9 above. 


\section{Elizabeth Lomax}

treatment usually adopted, according to Tanner, "consists in the administration of those vegetables, which are remarkable for their antiscorbutic qualities, such as oranges, lemons, potatoes, lime-juice...". ${ }^{30}$ However, some physicians believed that the pure acid could replace the fruit juice (the former was easier to preserve, an important factor in provisioning ships), while acid rinses were a time-honoured method of trying to improve the cleanliness of an infected mouth.

In France, much more was written about the possibility of scurvy in small children, yet the impact was negligible because, as will be seen, the allusions were either too casual to command attention, or else too confused to assist understanding. Muddled complexity was exemplified in Antoine Portal's contributions to the subject at the turn of the century. In his opinion, rickets was rarely primary but usually the consequence of some antecedent disease, particularly venereal illness, scrofula, scurvy, eruptive fevers, abdominal enlargement, and rheumatism or gout. ${ }^{31}$ However, in Portal's 1797 monograph on rickets, all the cases described as essentially scorbutic referred to older children or adults. In 1808 , by which time he was professor of medicine at the Collège de France, Portal reconsidered the connexion between syphilis, scrofula, scurvy, and rickets in a lecture to the Institut Français on the nature and treatment of hereditary disease.$^{32}$ Now, he was indicting venereal illness as the original cause of degenerative, and hereditary, conditions such as scrofula, rickets, and scurvy. The latter two maladies he thought quite commonplace, basing this claim on the frequency with which his patients were cured with antiscorbutic remedies. "My success was great", Portal asserted, "and numerous infants, whose spines or limbs were distorted, were restored to perfect symmetry of shape. Others, in whom the rachitis was confined to deformities in the bones of the cranium and chest, were completely cured." One of his favourite remedies combined juice extracted from scurvy grass, watercress, and horseradish with corrosive sublimate (a mercurial compound included because of his conviction that syphilis was probably the original cause of illness), the whole made up to a syrup to be taken daily.

It is possible that some of the babies so treated were suffering from scurvy combined with rickets, and so benefited from Portal's therapy. But these references to practice were mainly buried in a footnote, and their impact was therefore minimal, while the main thrust of the essay was on the secondary, and hereditary, nature of many maladies considered primary by other physicians. To support this hereditary theme, Portal revived the seventeenth-century notion of a scorbutic constitution in opposition to the concept of a specific disease of environmental origin. In his 1753 Treatise of the scurvy, James Lind had contemplated the possibility of a scorbutic habit, or predisposition to the illness. He admitted that some people acquired the malady more easily than others, but thought it far from probable "that this is what may properly be called a hereditary or connate disease; as we seldom in practice see it rise to a great height, without the influence of some obvious external causes; and,

${ }^{30}$ Tanner, op. cit., note 9 above, p.195.

${ }^{31}$ Antoine Portal, Observations sur la nature et sur le traitement du rachitisme, Paris, Merlin, 1797, p.8.

${ }^{32}$ Antoine Portal, 'Considerations on the nature and treatment of some hereditary or family diseases', Lond. med. phys. J., 1809, 21: 229-239, 281-296. 


\section{Difficulties in diagnosing infantile scurvy}

experience shews, that when the taint is but slight and beginning, it may for the most part be quickly and easily subdued." constitutions" became rarer, and some of Portal's listeners and readers may have been antagonized by his revival of the concept. One such was Joseph Adams, honorary secretary to the Medical Society of London, who fiercely criticized Portal's loose usage of terms such as familial, hereditary, and connate.$^{34}$ Adams did not mention scurvy in particular, but made it perfectly clear that he considered the content of the Frenchman's essay to be mostly ill-judged and erroneous.

Other French physicians more simply associated severe inflammation and bleeding during teething with scurvy. Thus, in 1799, Nicholas Chambon, having described rather vividly occasional gangrene and putrefaction of the gums, commented that he had observed such effects "in children liable to scurvy, and most commonly for obvious reasons in scorbutics". ${ }^{35}$ Nearly thirty years later, Charles $\mathrm{M}$. Billard, in his Treatise on the diseases of the newborn, also mentioned the possibility of scurvy in connexion with some cases of difficult teething involving congestion, inflammation, softening, bleeding, and ulceration of the gums. "This illness occurs from the tenderest age until the first teeth have appeared. It must not be confused with gangrene of the mouth, which has been discussed earlier, and would seem to be more closely related to the scurvy of adults." 36 But Billard then illustrated his point with case histories of two infants less than a month old, that is edentulous children in whom bleeding gums would be symptomatic of a haemorrhagic disorder other than scurvy.

Billard had sought to differentiate scurvy from gangrene of the mouth, a horrible and usually fatal disorder seen in children reared under the worst conditions. Since the seventeenth century, cases had been described in most European countries and in America, but physicians disagreed as to the precise boundaries and whether or not a milder condition of ulceration of the mouth (ulcerative stomatitis) was the forerunner of the dreaded gangrene (cancrum oris, noma) ${ }^{37}$ By the nineteenth century, debate had extended to the underlying pathology, with some French and German physicians perceiving the gangrene as scorbutic in origin, while others saw it as the end result of cancer or syphilis. In 1852, Drs Bouley and Caillault, after excluding diphtheria, claimed that all remaining afflictions involving deep-seated ulceration and gangrene were of scorbutic nature.$^{38}$ Scurvy was incriminated, they believed, because of the coexistence of severe wasting, extravasations of blood into the skin, ulceration of the gums and mouth, oedema of the limbs, and diarrhoea. Their paper was based on forty-six cases of gangrene, including gangrene of the vulva, perineum, and axillae, in children aged between two and ten.

\footnotetext{
${ }^{33}$ James Lind, A treatise of the scurvy, Edinburgh, Sands, Murray \& Cochran, 1753, p.65.

${ }^{34} \mathrm{Joseph}$ Adams, $A$ treatise on the supposed hereditary properties of disease, London, J. Callow, 1814.

${ }^{35}$ Nicholas Chambon de Montaux, Des maladies des enfans, Paris, A.J. Dugour et Durand, 1799, vol.2, p.93.

${ }^{36}$ Charles Michel Billard, Traité des maladies des enfans nouveau-nés at à la mamelle, Brussels, $\mathrm{H}$. Dumont, 1835 (first ed. 1828), p.154.

${ }^{37}$ For a bibliography, see: 'Noma', Dictionnaire encyclopédique des sciences médicales, vol. 13, Paris G. Masson, 1979, pp.335-336.

${ }^{38} \mathrm{M}$. Bouley and C. Caillault, 'Mémoire sur les affections phagédéniques et gangréneuses chez les enfants, et sur leurs nature scorbutique', Gaz. méd., 1852, Sér. 3, 7: 418, 433, 512, 523, 667, 702.
} 


\section{Elizabeth Lomax}

The following year, Antoine Barthez and Frédéric Rilliet devoted a chapter of their famous paediatric textbook to a discussion of the cause of cancrum oris, finally concluding that scurvy was merely one of several cachexias that could terminate in gangrene. ${ }^{39}$ In their experience, measles was by far the commonest antecedent. Of ninety-eight cases of gangrene of the mouth, forty-one had presented as complications of measles, whereas only two appeared to be the consequence of scurvy. ${ }^{40}$ Fatal pneumonia or haemorrhage usually set in so rapidly that no particular remedy, including antiscorbutics, seemed particularly effective. By modern standards, Rilliet and Barthez's evaluation was remarkably accurate, for cancrum oris (gangrenous stomatitis, noma) is now considered as a malignant but non-contagious infection by Vincent's organism in a child with greatly reduced resistance due to a combination of nutritional deprivation and previous infection, most frequently measles. The disease is now rarely seen in developed countries and responds well to penicillin. ${ }^{41}$

In the pre-bacteriological era, oral lesions due to Vincent's infection could easily have been confused with those due to scurvy. So, while some physicians considered the whole lot to be scorbutic in nature, others simplified matters in the other direction by labelling everything as gangrene of the mouth. One such was Auguste Le Dentu, who, in an 1871 article on the surgical pathology of the face, wrote extensively on gangrene without mentioning the possibility of scurvy. ${ }^{42}$ In his list of references for "gangrene of the face", Le Dentu included titles where scurvy figured prominently without considering any explanation necessary. One such was an eighteenth-century paper entitled 'Gangrène scorbutique des gencives chez les enfants'. ${ }^{43}$ The author, a surgeon named Berthe, described the illness of a boy first seen at the age of two in 1754 . The infant was very sick and querulous, with sore, bleeding gums, black stools, swollen and painful knee joints, and oedematous feet and hands. Berthe treated the child with antiscorbutic remedies including vegetable soup, but full recovery took eighteen months with several relapses along the way. The description of events supports Berthe's diagnosis of scurvy, but Le Dentu seems to have considered it a case of noma.

In Britain, infantile scurvy could also have masqueraded as gangrene of the mouth. Copland, for example, recognized a condition he called stomatitis phagedenica, with cancrum oris, noma, and gangrenous stomatitis as synonyms. ${ }^{44}$ In his opinion, attempts to differentiate a scorbutic form of this illness were unrealistic, and he too included Berthe's and other papers presuming to deal with scurvy in his list of references. For him, stomatitis phagedenica was a distinct entity easily distinguished

\footnotetext{
${ }^{39}$ Antoine-C.-E. Barthez and Frédéric Rilliet, Traité clinique et pratique des maladies des enfants, Paris, Germer Baillière, 1853, vol. 2, pp.346-390.

${ }^{40}$ Ibid., p.384.

${ }^{4}$ Arnold H. Einhorn, 'The mouth', in Henry L. Barnett (editor), Pediatrics, New York, Appleton-Century-Crofts, 1968, pp.1647-1658.

${ }^{42}$ Auguste Le Dentu, 'Face - pathologie chirurgicale', Nouveau dictionnaire de médecine et de chirurgerie pratique, Paris, J.B. Baillière, 1871, vol. 14, pp.472-510.

${ }^{43} \mathrm{M}$. Berthe, 'Sur la gangrène scorbutique des gencives dans les enfans', Mém. Acad. roy. Chirg., 1774, 14: 193-217.

“James Copland, 'Stomatitis phagedenica', Dictionary of practical medicine, vol. 3, New York, Harper, 1860, pp.1022-1024.
} 


\section{Difficulties in diagnosing infantile scurvy}

from other less fatal forms of stomatitis. But other British medical writers were less definite. Richard Evanson and Henry Maunsell, professor of medicine and professor of midwifery respectively in Dublin, discussed gangrene of the mouth apart from cancrum oris..$^{45}$ The former, they found, occasionally attacked very debilitated infants, beginning with swelling of the cheek, whereas the latter was rarely seen in children under eighteen months old, and generally commenced in the gums. West wrote quite extensively on gangrenous stomatitis, but much of his account was derived from the continental literature, since he himself had only observed ten cases by the $1860 \mathrm{~s} .{ }^{46} \mathrm{He}$ was in general agreement with the interpretation proposed by Rilliet and Barthez, and made no mention of the scorbutic connexion advanced by some French and German physicians.

The concept of a scorbutic form of gangrenous stomatitis failed to gain general acceptance because it was too diffuse and lacked clinical criteria or even practical consequences. In a couple of their case histories, Bouley and Caillault did refer to the use of antiscorbutics, including lemon juice, but, since the patients died in spite of such treatment, this was no evidence of correct diagnosis. For the rest, they made no mention of treatment or else used the more standard method of cauterization of the ulcers. They had convinced themselves on clinical grounds of the scorbutic nature of oral gangrene, but offered no convincing reason why other physicians should do likewise. Also rejected by other practitioners was the less sweeping, and probably more accurate suggestion, made by the German physician A.L. Richter, that noma should be separated into three types, of which one was scorbutic in origin ${ }^{47}$ Rilliet and Barthez may have summed up the general mood when they remarked that the above papers lacked persuasion because they glossed over any precise definition of scurvy. ${ }^{48}$

Precision was impossible on clinical criteria alone. As Leonard Wilson and others have shown, Barlow succeeded in establishing the specificity of infantile scurvy because he related the main clinical sign of exquisite tenderness in the limbs with autopsy findings of periosteal haemorrhage, and in other patients reversed the course of the disease with antiscorbutic remedies. ${ }^{49} \mathrm{He}$ also demonstrated how the disease in babies differed from that in adults, so establishing a new clinical entity Barlow's disease - for paediatricians. By the early twentieth century, "acute rickets" was an abandoned proposition, as were suggestions of a scorbutic form of noma. Instead, physicians were beginning to recognize Barlow's disease. According to Jules Comby, "the first case of infantile scurvy, or Barlow's disease, that was identified as such in France, was placed on record by Moizard, in December 1897". ${ }^{\circ 0}$ By 1919,

\footnotetext{
${ }^{45}$ Richard T. Evanson and Henry Maunsell, $A$ practical treatise on the management and diseases of children, Dublin, J. Fannin, 1836, pp.222-224.

${ }^{46}$ West, op. cit., note 27 above, pp.462-468.

${ }^{47}$ Adolph I. Richter, Der Wasserkrebs der Kinder, Berlin, T.C.F. Enslin, 1828.

${ }^{48}$ Barthez and Rilliet, op. cit., note 39 above, p.351.

${ }^{49}$ Leonard G. Wilson, 'The clinical definition of scurvy and the discovery of vitamin C', J. Hist. Med., 1975, 30: 40-60; for accounts of the history of infantile scurvy, see also, Alfred F. Hess, Scurvy, past and present, Philadelphia, J.B. Lippincott, 1920, pp.10-15; and P.G. Shipley, 'Our fathers and the "scorby"', J. Amer. diet. Assoc., 1929, 5: 1-10.

so Jules Comby, 'Infantile scurvy', Bost. med. surg. J., 1919, 180: 336-338.
} 


\section{Elizabeth Lomax}

Comby himself had observed no less than forty-two cases. In the meantime, rickets had been restored to its former status of an insidiously developing chronic illness, and noma had also become a more circumscribed disease.

\section{ACKNOWLEDGEMENTS}

I should like to express my thanks to Thomas E. Cone, Jr, MD, for assistance and advice in preparing this paper. 